\title{
Ecological observations on the gorgonian sea fan Eunicella cavolinii in the Bay of Naples
}

\author{
Anthony R. Russo* \\ Reparto Ecologia Marina della Stazione Zoologica Napoli, 80077, Ischia Porto, Italy
}

\begin{abstract}
Sea fans Eunicella cavolinii (Gorgonacea) do not grow above $15 \mathrm{~m}$ water depth on a vertical wall off the island of Ischia, Italy. There is a $90^{\circ}$ change in orientation from parallel to the sea surface above $20 \mathrm{~m}$ to perpendicular to the sea surface below that depth. The vertical component of wave motion seems to determine orientation above $20 \mathrm{~m}$, whereas below $20 \mathrm{~m}$ sea fans orient, as they do normally, to the horizontal water current. Sea fans were evenly spaced at all depths studied and did not overlap or shade one another. At 20 to $25 \mathrm{~m}$ gorgonians are larger in effective area than at 15 to $20 \mathrm{~m}$ and exhibit a greater size range.
\end{abstract}

\section{INTRODUCTION}

While the number of studies on shallow-water gorgonians has increased rapidly, these are outnumbered by the many ecological and biological studies (effects on distribution and abundance of temperature, light, salinity, current, substrate, sedimentation) on hermatypic reef-buliding corals (Barnes 1973, Buddemier \& Kinzie 1976, Jokiel \& Coles 1977).

Colonial shallow-water gorgonians possess zooxanthellae and, like hermatypic reef-building corals, may utilize products secreted from algae cells as an energy source (Wainright 1967). Therefore, the 3 factors important for photosynthesis are correspondingly important for gorgonian faunal distribution: depth, temperature and light (Kinzie 1973). In this study observations were made on geometry, orientation and spatial distribution of the Mediterranean sea fan Eunicella cavolinii, a colonial sessile filter feeder which removes microzooplankton from water currents flowing orthogonal to its greatest effective cross sectional area. The study site was a sheer basalt wall extending to a depth of $40 \mathrm{~m}$ off Punta San Pancrazio on the Island of Ischia in the Bay of Naples, Italy (Fig. 1). E. cavolinii lives in great abundance in the Bay of Naples. It exhibits maximal growth on hard vertical substrates at depths between 8 and $30 \mathrm{~m}$. It is found down to $150 \mathrm{~m}$, but only in patchy formations.

\footnotetext{
- Present address: Science Division, Leeward Community College, University of Hawaii, Pearl City, Hawaii 96782, USA
}

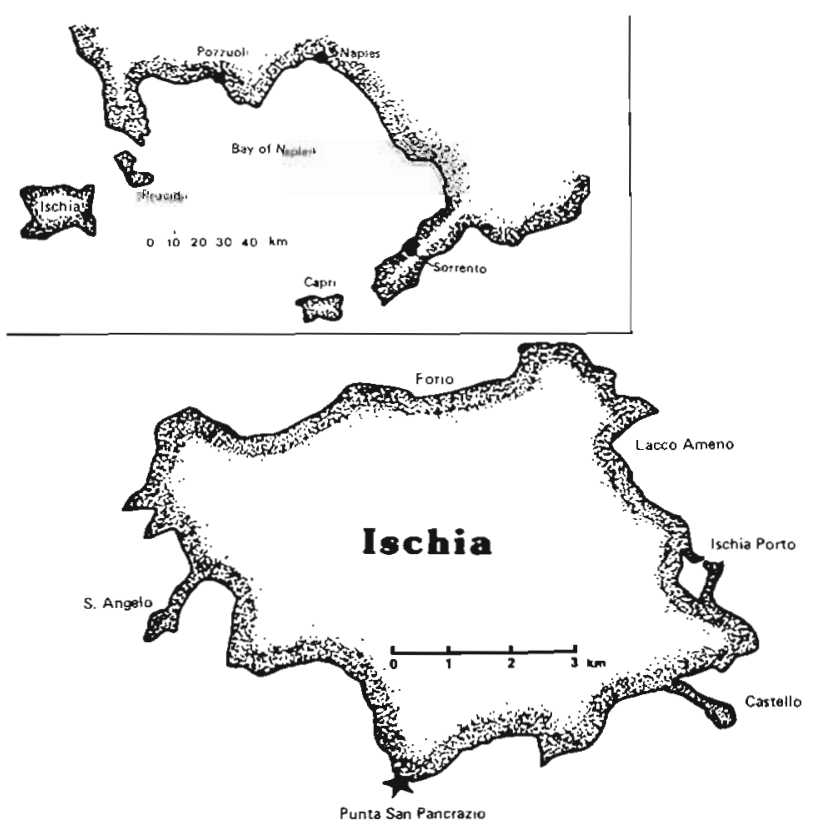

Fig. 1. Study site

\section{METHODS AND MATERIALS}

Gorgonians were removed from depths of $15,20,25$, and $30 \mathrm{~m}$ using SCUBA and brought back to the laboratory. After drying for $48 \mathrm{~h}$, they were mounted on $1 \times 1 \mathrm{~cm}$ graph paper with cellulose tape. Their outlines were traced onto the paper, and their effective areas determined by counting squares occupied by the 
trace and represented as a percentage of the total cross sectional rectangular area formed by the product of gorgonian width by length. Maximum length is the distance from the base of the gorgonian to its highest point; maximum width, the largest dimension orthogonal to it. Gorgonians were picked at random and measured for maximum lengths and widths at 15,20 , 25 and $30 \mathrm{~m}$ depths.

Orientation of Eunicella cavolinii was recorded while diving, and any major change in orientation with depth was documented by taking a census of mean orientation at various depths. Depths were determined using a standard depth gauge. An orientation parallel to the sea surface was used as $0^{\circ}$.

Spacing measurements were made within a $2 \mathrm{~m}$ strip between $15 \mathrm{~m}$ and $20 \mathrm{~m}$ (Area 1) and between 20 and $25 \mathrm{~m}$ (Area 2). The nearest-neighbor distances between each pair of sea fans were measured and the pattern analyzed using the method of Clark \& Evans (1954) and variance to mean ratios (Pielou 1974). Current speed and direction were measured using a Savonius rotor current meter. The period of the swell striking the wall at Punta San Pancrazio was measured using a stop watch. Measurements of current and period were taken every day for $2 \mathrm{wk}$ and averaged.

\section{RESULTS}

The gorgonian sea fan Eunicella cavolinii, which grows on a sheer basalt wall off Punta San Pancrazio on the island of Ischia in the Bay of Naples, was not present at depths less than $15 \mathrm{~m}$. Sea fans were observed at depths from $15 \mathrm{~m}$ to the bottom at $40 \mathrm{~m}$. Results of spacing measurements (Table 1) show that gorgonians are evenly spaced throughout the entire

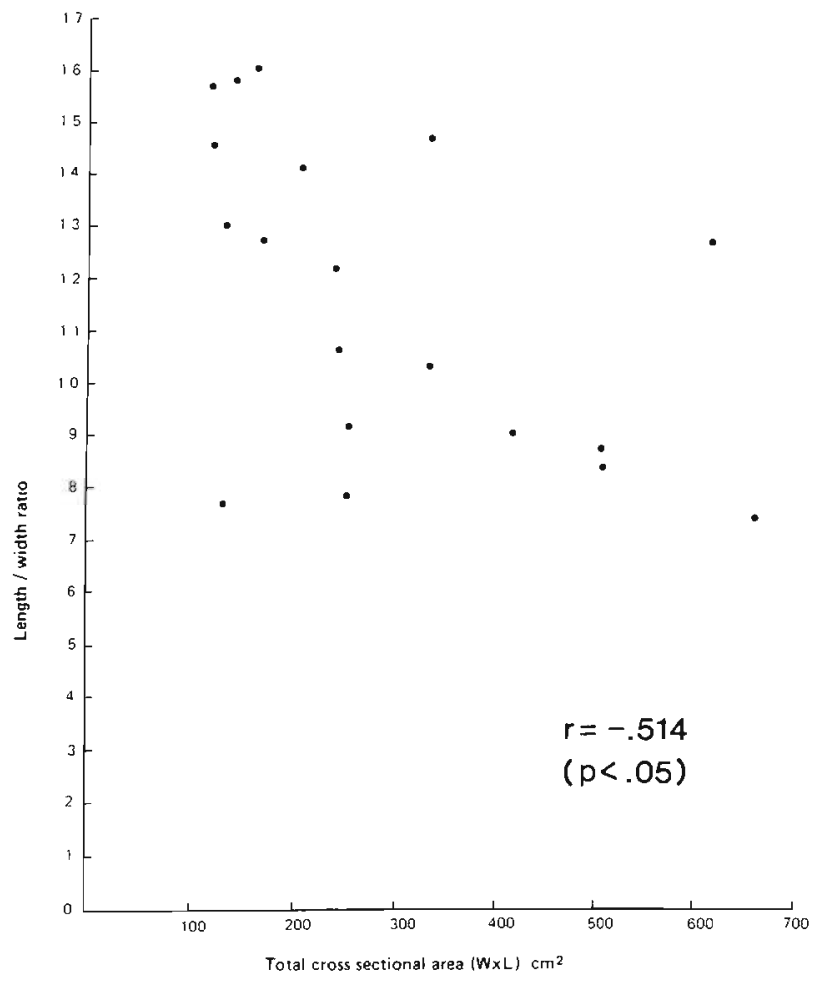

Fig. 2. Eunicella cavolinii. Variation of L/W with total cross sectional area; Punta San Pancrazio, Bay of Naples (15 to $20 \mathrm{~m}$ )

depth range observed. Mean distance between neighboring gorgonians is $35.7 \mathrm{~cm}$ in the 15 to $20 \mathrm{~m}$, and 52.3 $\mathrm{cm}$ in the 20 to $25 \mathrm{~m}$ depth range. The ratio width (W) to average distance between neighboring attachment sites $(\overline{\mathrm{r}})$ is less than 0.5 at both depths. This ratio is a measure of overlap or 'shading' by one fan with its neighbor.

Gorgonians growing on the wall off Punta San Pan-

Table 1. Eunicella cavolinii. Spacing and geometric data

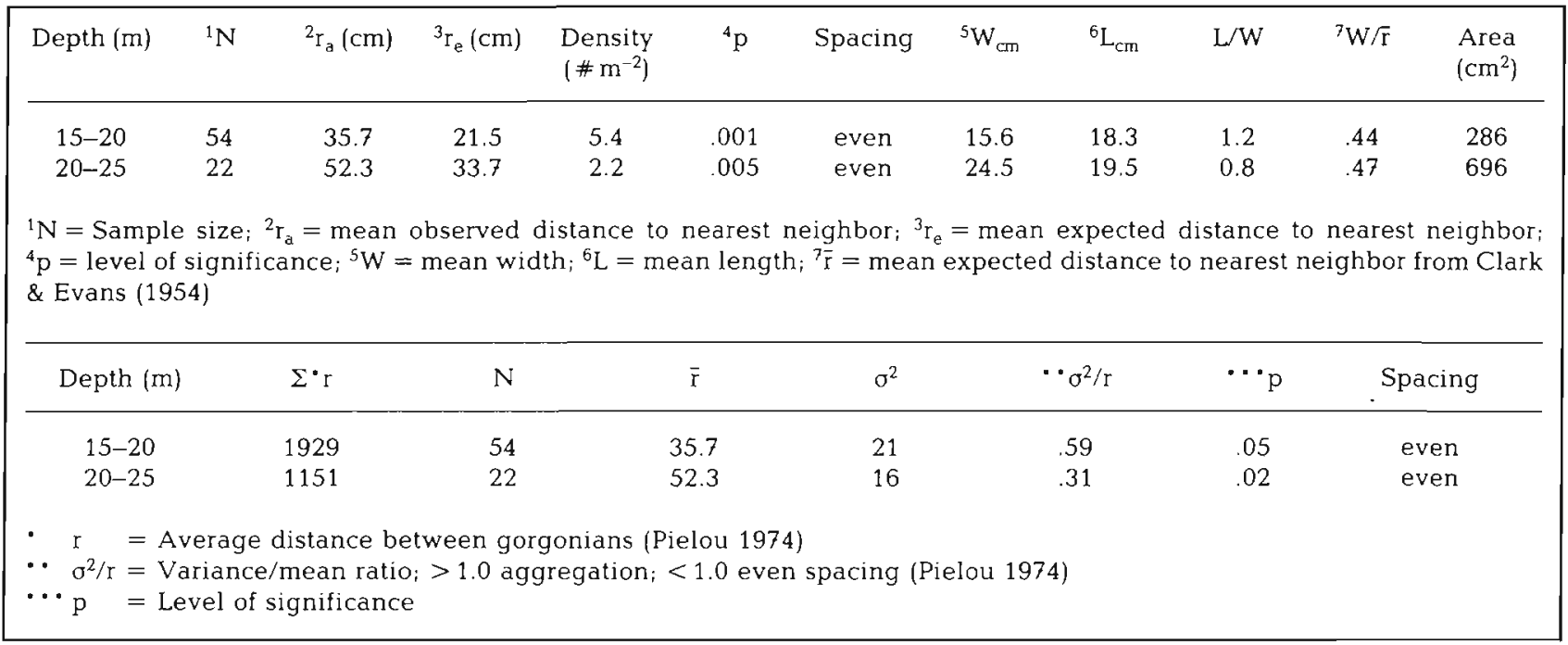




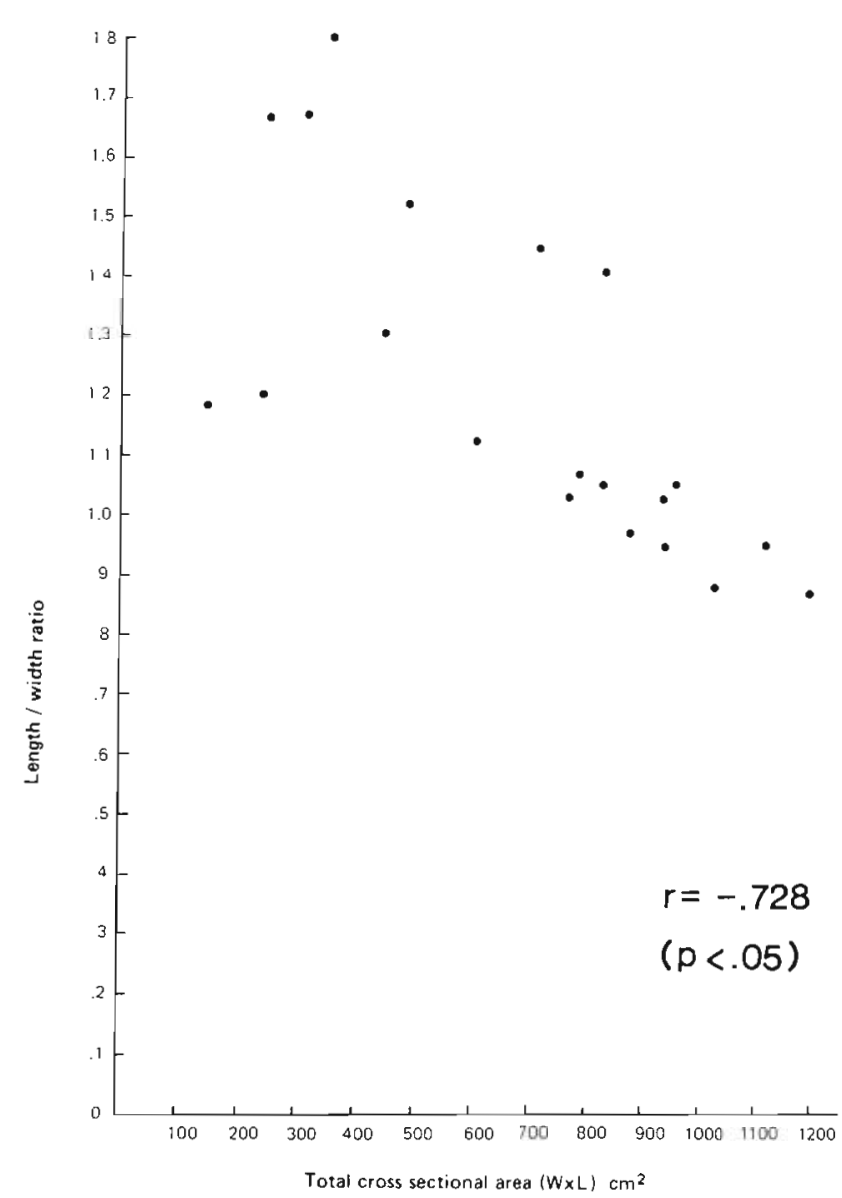

Fig. 3. Eunicella cavolinii. Variation of L/W with total cross sectional area; Punta San Pancrazio, Bay of Naples (20 to $25 \mathrm{ml}$

crazio at 15 to $20 \mathrm{~m}$ are oriented without exception parallel to the sea surface; below $20 \mathrm{~m}$ their orientation changes abruptly by $90^{\circ}$. Results of a standard t-test and a non-parametric Wilcoxan 2 sample test show a significant difference between effective sea fan areas at 15 to $20 \mathrm{~m}$ and 20 to $25 \mathrm{~m}(\mathrm{p}=.001$ and .02$)$. Gorgonians at 20 to $25 \mathrm{~m}$ are significantly larger $\left(A=696 \mathrm{~cm}^{2}\right)$ than those at 15 to $20 \mathrm{~m}\left(\mathrm{~A}=286 \mathrm{~cm}^{2}\right)$ (Table 1). An F-test comparing variances at both depths showed that the gorgonian population at 20 to $25 \mathrm{~m}$ has a greater size range than the population at 15 to $20 \mathrm{~m}(\mathrm{p}<.05)$. Sizes ranged from 126 to $616 \mathrm{~cm}^{2}$ at 15 to $20 \mathrm{~m}$ and from 143 to $1200 \mathrm{~cm}^{2}$ at 20 to $25 \mathrm{~m}$. Fig. 2 \& 3 show the relation of the length-to-width-ratio with the total rectangular area (WxL) for Eunicella cavolinii at 15 to $20 \mathrm{~m}$ and 20 to $25 \mathrm{~m}$ depth ranges, respectively. There is a linear negative correlation between the 2 variables at both depths. The correlation is higher between 20 and $25 \mathrm{~m}(\mathrm{r}=-.73)$ than at 15 to $20 \mathrm{~m}$ $(\mathrm{r}=-.51)$. The width grows more rapidly than the length as the cross sectional area of the gorgonian increases.
Table 2. Eunicella cavolinii. Effective area expressed as percentage of total rectangular area

\begin{tabular}{|crcc|}
\hline $\begin{array}{c}\text { Depth } \\
(\mathrm{m})\end{array}$ & $\begin{array}{c}\mathrm{W} \\
(\mathrm{cm})\end{array}$ & $\begin{array}{c}\mathrm{L} \\
(\mathrm{cm})\end{array}$ & $\begin{array}{c}\text { Effective area } \\
(\%)\end{array}$ \\
\hline 15 & 9.0 & 14.2 & 15.20 \\
15 & 13.5 & 17.7 & 14.60 \\
15 & 16.5 & 15.0 & 15.85 \\
15 & 15.5 & 22.2 & 15.60 \\
20 & 27.0 & 28.2 & 15.10 \\
20 & 19.6 & 27.5 & 14.80 \\
20 & 18.0 & 14.0 & 16.10 \\
20 & 10.0 & 16.0 & 16.97 \\
25 & 11.0 & 13.3 & 15.50 \\
25 & 15.5 & 15.0 & 13.90 \\
25 & 30.0 & 29.3 & 14.78 \\
30 & 25.0 & 19.5 & 15.74 \\
30 & 34.2 & 30.5 & 14.93 \\
30 & 18.5 & 24.0 & 14.95 \\
& & & \\
Mean $=15.287$ & $\mathrm{SD}=.75103$ & var $=.564$ & $\mathrm{n}=14$ \\
\hline
\end{tabular}

Table 2 shows the percent effective areas for 14 samples taken from various depths throughout the depth range studied (15 to $40 \mathrm{~m}$ ). The relation between percentage effective area and total rectangular area (WxL) is fairly constant, independent of depth $(\overline{\mathrm{x}} \%=15.28- \pm .75)$. Measurements of current speed and direction show that currents off Ischia were southward along the western coast during the period of study, averaging about $9 \mathrm{~cm} \mathrm{~s}^{-1}$ down to a depth of 40 $\mathrm{m}$. The average wave period was calculated to be $6.7 \mathrm{~s}$.

Fig. 4 shows the variation of vertical wave velocity at

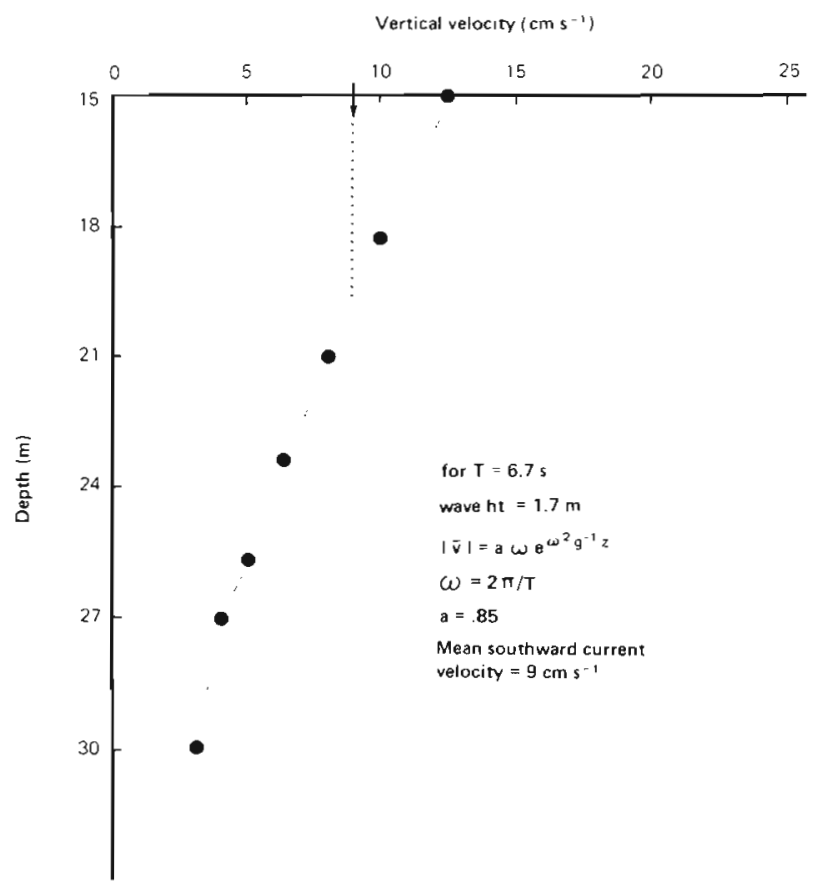

Fig. 4. Vertical water velocity at the wall vs depth; Punta San Pancrazio, Bay of Naples 
the wall with depth. Vertical wave oscillation decreases exponentially as predicted by theory reaching $9 \mathrm{~cm} \mathrm{~s}^{-1}$ at about $20 \mathrm{~m}$ (Fig. 4). At the wall, the wave equation simplifies to the algorithm for the vertical velocity of water molecules (V) as a function of wave period (T), depth (Z) and wave amplitude (a) which equals 0.5 wave height.

\section{DISCUSSION}

Eunicella cavolinii was not found in water depths less than $15 \mathrm{~m}$ off Punta San Pancrazio, Ischia in the Bay of Naples. Discussing the depth regime of $E$. cavolinii in the Bay of Naples off Cape Sorrento, Riedl (1972b) found that it grows in water depths of below 8 m. Theodor \& Denizot (1963) report that the $15 \mathrm{~m}$ depth limit for this species extends throughout most of the Mediterranean Sea. This abrupt growth pattern is also consistent with other observations on shallow-water gorgonians in Florida (Opresko 1973). The upper bathymetric limit of distribution seems to be more sharply defined than the lower limit.

Gorgonians were evenly spaced throughout the observed depth ranges (15 to $20 \mathrm{~m}$ and 20 to $25 \mathrm{~m}$ ) off Punta San Pancrazio. The average distance between neighboring sea fans at 20 to $25 \mathrm{~m}$ is greater than at the 15 to $20 \mathrm{~m}$ depth range. The ratio of sea-fan width to mean distance to the nearest neighbor is less than 0.5 at both depths. There is little or no overlap or 'shading' between adjacent gorgonians. As the width of the sea fan increases with depth so does the average distance between attachment sites (stems). Gorgonian spacing seems to reflect a spacing pattern most efficient in partitioning the resources of food or minerals carried by the water to the effective area of the gorgonians.

Gorgonians growing on the sheer face of the wall from 15 to $20 \mathrm{~m}$ are oriented without exception with their flat broad surfaces parallel to the sea surface. Below $20 \mathrm{~m}$, orientation changes abruptly by $90^{\circ}$. The effects of vertical oscillations of water due to waves are important for gorgonians in shallow water (Kinzie 1973); these organisms take advantage of oscillating water by orienting their cross sections perpendicular to them. Any horizontal unidirectional flow of water is likely to influence benthic organisms at depths where appreciable currents flow (Riedl 1972a, Muzik \& Wainright 1977).

Below $20 \mathrm{~m}$, off Punta San Pancrazio, Eunicella cavolinii orients itself normal to the prevailing current. Gorgonian orientation has been used as an indicator of mean current patterns (Barham \& Davies 1968, Riedl $1972 b$ ). California gorgonians orient normal to mean tidal currents. Muricea orient at right angles to bottom surge in shallow water $(<30 \mathrm{~m})$ while Adelogorgia orient normal to tidal currents in greater depths $(>30$ m) (Grigg 1972). Riedl (1972b) defines 2 major water movement zones in the Bay of Naples (Cape Sorrento) which affect $E$. cavolinii: the oscillating zone $(<11 \mathrm{~m})$ and the unidimensional flowing zone $(>11 \mathrm{~m})$. I found the critical depth of orientation for E. cavolinii off Punta San Pancrazio to be at $20 \mathrm{~m}$. The difference in critical depth is probably due to differences in wave exposure. Above $20 \mathrm{~m}$ wave period and wave height determine vertical water motion; below that depth the southward current $\left(9 \mathrm{~cm} \mathrm{~s}^{-1}\right)$ along the western coast of Ischia prevails.

Hydromechanical properties of a sea fan colony are important for its survival. Water velocity inside the branches of sea fans depends on their morphology and orientation to water movement. In corals perpendicular to water flow, exit velocity is $30 \%$ less than entrance velocity (Chamberlain \& Graus 1975). This property may enhance capture of food (Laborel 1960). However, Lasker (1981) reports that some species of gorgonian do not efficiently capture zooplankton due to low densities of nematocysts in their tentacles. Some gorgonians capture more food when oriented parallel to water flow (Leversee 1976). The orientation of sea fans normal to water flow may not be related to food capture but to waste removal in the vicinity of the polyps and a resupply of mineral nutrients $(\mathrm{Ca}, \mathrm{Mg}$ ) for skeletal growth.

Gorgonians living off Punta San Pancrazio are significantly larger $(\mathrm{p}=.05$ ) at 20 to $25 \mathrm{~m}$ than in shallow waters. The thermocline off Punta San Pancrazio extended to a depth of 10 to $12 \mathrm{~m}$. Temperature differences between 15 and $25 \mathrm{~m}$ were no greater than 1 to 2 $\mathrm{C}^{\circ}$. However, at $15 \mathrm{~m}$ the effects of seasonal variations in wave activity, total solar radiation, mixing and depth of the thermocline may ecologically be more important for gorgonians than at depths near $25 \mathrm{~m}$ where severe surface wave activity is rare. Gorgonians growing on a vertical face receive less light than those growing on horizontal substrata due to differences in the declination of the sun and reflection/refraction properties of water. Light has an important effect on hermatypic gorgonians since they may obtain some of their nutritional energy from photosynthesizing zooxanthellae (Wainright 1967). Too much light can smother gorgonians by epiphytic growth (Kinzie 1973) and if zooxanthellae are contributing to gorgonian nutrition it is more important in low light regimes (Theodor \& Denizot 1963). Populations of Eunicella cavolinii growing at 20 to $25 \mathrm{~m}$ off Punta San Pancrazio have a greater size range than populations at 15 to 20 $m$. This is probably due to seasonal changes in mixing, turbidity and light availability. The difference in gorgonian size distribution reflects differences in longterm mean water movement, temperature and light. 
At both depth sites the width of Eunicella cavolinii increased faster than its length (Fig. 2 \& 3). A faster increase in length may be disadvantageous due to an increased bending moment (force $\times$ length). For a flexible sea fan an increase in bending moment decreases the effective cross sectional area obstructing water flow. At an orientation $90^{\circ}$ to the water current, there is also no twisting moment (Wainright \& Dillon 1969). Turbulence due to eddy flow is important for sea-fan growth (Gust 1977) and E. cavolinii orientation may reflect a trade-off between increased bending moments and drag due to normal orientation, and the benefits of increased eddy flow. The hydrodynamically effective area of $E$. cavolinii may be a constant percentage $(15 \%)$ of its total rectangular area (LxW). However, present sample size $(n=14)$ is too small to allow definite conclusions.

Acknowledgements, I extend special thanks to Helen Baligad. The hospitality of Eugenio Fresi, Director of the Ischia Marine Station, is much appreciated.

\section{LITERATURE CITED}

Barham, E., Davies, J. (1968). Gorgonians and water motion studies in the Gulf of California. Underwat. Nat. 5(3): 24

Barnes, D. (1973). Growth in scleractinians. Bull. mar. Sci. 23 : 280-298

Buddemier, R., Kinzie R. (1976). Coral growth. Oceanogr. mar. Biol. A. Rev. 14: 183-225

Chamberlain, J., Graus, R. (1975). Water flow and hydromechanical adaptations of branched reef corals. Bull. mar. Sci. 25: 112-125

Clark, P., Evans, F. (1954). Distance to nearest neighbor as a measure of spatial pattern. Ecology 35: 445-453
Grigg, R. (1972). Orientation and growth form of sea fans. Limnol. Oceanogr. 17: 185-192

Gust, G. (1977). Turbulence and waves inside flexible wall systems designed for biological studies. Mar. Biol. 42: $47-53$

Jokiel, P., Coles, S. (1977). Effects of temperature on the mortality and growth of Hawailan reef corals. Mar. Biol. 43: 201-208

Kinzie, R. (1973). The zonation of West Indian gorgonians. Bull. mar. Sci. 23: 93-155

Laborel, G. (1960). Contribution and l'etude directe des peuplements benthique sciaphules sur substrat rocheux in Mediterranee. Rec. Trav. Stat. Mar. Endoume 33: 20-30

Lasker, H. (1981). A comparison of the particulate feeding abilities of three species of gorgonian soft coral. Mar. Ecol. Prog. Ser. 5: 61-67

Leversee, G. (1976). Flow and feeding in fan shaped colonies of the octocoral Leptogorgia virgulata. Biol. Bull. mar. biol. Lab., Woods Hole 151: 344-356

Muzik, K., Wainright, S. (1977). Morphology and habitat of five Fijian sea fans. Bull. mar. Sci. 27: 308-337

Opresko, D. (1973). Abundance and distribution of shallow water gorgonians in the area of Miami, Florida. Bull. mar. Sci. 23: $533-558$

Pielou, E. C. (1974). Population and community ecology. Gordon Breach Publs., New York

Riedl, R. (1971a). Water movement: general introduction. In: Kinne, O. (ed.) Marine ecology, Vol. I, Environmental factors, Part 2. Wiley, London, p. 1085-1089

Riedl, R. (1972b). Water movement: animals. In: Kinne, O. (ed.) Marine ecology, Vol. I, Environmental factors, Part 2. Wiley, London, p. 1123-1156

Theodor, J., Denizot, R. (1963). Contribution a l'etude des gorgones. Trois formes adaptives d' E. stricta and fonction de la turbulence et due courant. Vie Milieu 16: 815-818

Wainright, S. (1967). Diurnal activity of hermatypic gorgonians. Nature, Lond. 216: 1041

Wainright, S., Dillon, J. (1969). On the orientation of sea fans. Biol. Bull. mar. biol. Lab., Woods Hole 136: 130-139 